(Griffith, A. H.-Norris and Oliver). "System of Diseases of the Eye." Vol. III, p 355, 1898.

Groes-Petersen.-Klin. Monatsbl. f. Augenheilk., Vol. L (ii) p. 159, 1912. HА м, A.-Klin. Monatsbl. f. Augenheilk., Vol. LII, p. 484, 1914.

Hancock, W. I.-Roy. Lond. Ophthal. Hosp. Reps., Vol. XVI, p. 150, 1906. HEPBURN, M. L. (1)-Trans. Ophthal. Soc. U.K., Vol. XXXII, p. 361, 1912. - (2)-Roy. Lond. Ophthal. Hosp. Reps., Vol. XVIII, p. 92, 1912. (3)-Roy. Lond. Ophthal. Hosp. Reps., Vol. XIX, p 398. 1914. von HIPPEL, E.-Ophthal. Review, Vol. XXXIII, p. 50, 1914.

VAN DER HOEVE, J.-Klin. Monatsbl. f. Augenheilk., Vol. LIII, p. 487, 1914. IGERSHEIMER, J.- " Syphilis und Auge," p. 441, 1918.

JENSEN, E.-Arch.f. Ophthal., Vol. LXIX, p. 41, 1908.

JESSOP, W. H.-Trans. Ophthal. Soc. U.K., Vol. XXXV, p. 311, 1915.

JUNiUs, P.-Arch.f. Augenheilk., Vol CVI, p. 475, 1932.

KNAPP, A.-Trans. Amer. Ophthal. Soc., Vol. XXXV, p. 259, 1937.

KöHNE, W.-Klin. Monatsbl. f. Augenheilk., Vol. LXV, p. 882, 1920.

LEBER, T.-Graefe-Saemisch. Handb. d. Augenheilk., Vol. VII, p. 786, 1915. LOdBerg, C. V.-Klin. Monatsbl. f. Augenheilk., Vol. LVI, p. 301, 1916.

LODDONI, G.-Zentralbl.f.d. ges. Ophthal., Vol. XXI, p. 364, 1929.

LÖFFLER, A.-Reichel. "Blutkörperchensenkung," 1936.

Lowenstein, A.-Klin. Monatsbl. f. Augenheilk., Vol. LXXVI, p. 816, 1926.

Macnamara, C.- "Manual of Diseases of the Eye," 1876.

ORMOND, A. W.-Proc. Roy. Soc. Med., Vol. VI (iii), p. 16, 1912.

Pallarés, J.-Klin. Monatsbl. f. Augenheilk., Vol. LXXXVI, p. 598, 1931.

RIEGER, H.-Arch. f. Ophthal., Vol. CXXXVI, p. 119, 1937.

RIEHM, W.-Klin. Monatsbl. f. Augenheilk., Vol. XC, p. 154, 1933.

RönNe, H. (1)-Arch. $f$. Augenheilk., Vol. LXXIV, p. 197, 1913.

(2)-Klin. Monatsbl. f. Augenheilk., Vol. LIV, p. 455, 1915.

SchertLin, G.-Klin. Monatsbl. f. Augenheilk., Vol. LVII, p. 60, 1916.

StatTI, L. W.-Arch.f. Ophthal., Vol. IX, p. 947, 1933.

TraqualR, H. M.- "Introduction to Clinical Perimetry," Chap. VI, 1938.

Tristaino, L.-Rassegna Ital. d'Ottal., Vol. V, p. 194, 1936.

VerhoefF, F. H. (1)-Trans. Amer. Ophthal. Soc., Vol. XIV, p. 568, 1916.

(2)-Trans. Amer. Ophthal. Soc., Vol. XXVI, p. 53, 1928.

Woods, A. C.-Amer. Jl. Ophthal., Vol. XXI, p. 366, 1938.

ZEEMAN, W. P. C.-Arch.f. Ophthal., Vol. CVI, p. 1, 1921.

ZentMAYER, W. (1)-Ophthal. Record, Vol. XVIII, p. 140, 1909.

(2)-Amer. Jl. Ophthal., Vol. V, p. 650, 1922.

\title{
A NEW NEEDLE-HOLDER
}

BY

\author{
H. B. Stallard
}

LONDON

THE needle-holder illustrated below in Fig. 1 shows certain modifications of the Silcock pattern. The handle, made of bakelite, is bulbous and shaped like that of an awl and other small carpentry

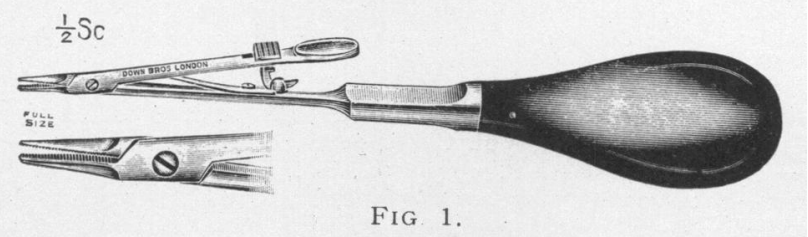


tools, thus fitting the hollow of the operator's hand comfortably and securely.

In front of the handle the shank of the needle-holder is made broad and flat with a curved shelving extremity at its base, the upper surface of which accommodates the operator's thumb. The releasing and fixing catch is surmounted by a small rectangular plate cross-grooved on its upper surface set at a slight inclination and resembling a miniature control pedal in a car.

The jaws of the holder are fined down and are considerably thinner than those of other holders. The opposed surfaces of the

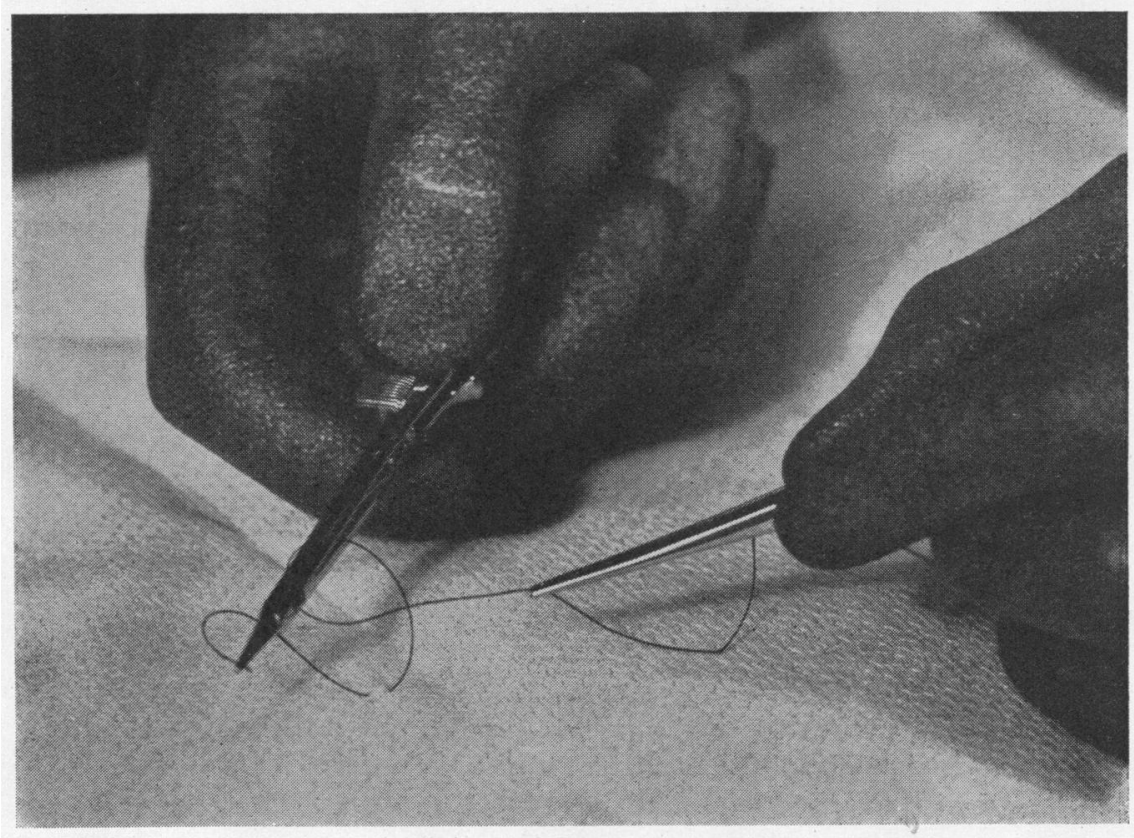

FIG. 2.

jaws are roughened by criss-cross grooving. The flanks of the holder are smooth and there are no projecting joints on which sutures may catch.

This needle-holder is designed for use in all ophthalmic operations. It may be manipulated in either hand, it holds securely very small needles such as corneo-scleral needles, and arterial needles used for suturing radon seeds to the sclera. It is particularly convenient for tying sutures in conjunction with forceps (see Fig. 2).

Its balance, security, ease of manipulation and smoothness of action are its chief merits upon which Down Bros. are to be congratulated for their workmanship. 